(C) 2013

Панікар I. I., кандидат ветеринарних наук

Полтавська державна аграрна академія

\title{
БІОХІМІЧНІ ОСОБЛИВОСТІ ФОРМУВАННЯ ПОРОСЯТ ПЕРШОЇ ДОБИ ЖИТТЯ
}

\section{Рецензент - доктор ветеринарних наук В. О. Свстаф'єва}

Рівень майже всіх показників клінічного метаболізму, а особливо білкових фракцій, у сироватці крові поросят у «домолозивному» періоді значно відрізняється від показників поросят першої доби життя, які отримували молозиво. Зміна показників білкового обміну пов'язана з надходженням 6 організм білків молозива. Підвищення активності АлАт, ЛДГ рівня вмісту глюкози, концентрації загального білірубіну за зниження лужної фосфатази та сечовини в крові свідчить про стресовий стан організму, шо можна пояснити стресовим фактором, отриманим організмом під час та відразу після народження.

Ключові слова: поросята, біохімічні показни$\kappa и$, білок, сечовина, білірубін.

Постановка проблеми. Збереження здоров'я молодняку сільськогосподарських тварин у ранньому віці є однією з найактуальніших проблем тваринництва України. Стабільність внутрішнього середовища організму тварин безпосередньо залежить від екологічних, техногенних та годівельних чинників зовнішнього середовища, що мають безпосередній вплив на формування й функціонування різних систем організму $[4,5]$. Економічні втрати від захворювань та загибелі продуктивного поголів'я, передусім молодняку, досить значні.

Аналіз останніх досліджень і публікацій, у яких започатковано розв'язання проблеми. У господарствах України в перші 8 тижнів життя гине до $25 \%$ отриманого приплоду поросят. Серед незаразної патології 80 \% припадає на шлунково-кишкові та респіраторні захворювання тварин. Це зумовлено низьким рівнем їх резистентності внаслідок недостатньої та неповноцінної годівлі, незадовільних умов утримання свиноматок у період вагітності, що призводить до порушення ембріонального розвитку, зниження вмісту імуноглобулінів, імунокомпетентних клітин, вітамінів, макро- і мікроелементів у молозиві та молоці $[10,12-15]$. Встановлено: що чим коротший інтервал між народженням і першим прийомом молозива, тим швидше імуноглобуліни, що знаходяться в ньому, всмоктуються в незміненому вигляді й забезпечують рівень колострального імунітету й профілактику шлунково-кишкових захворювань [1].

Метою даної роботи було встановлення рівня показників білкового обміну та активності індикаторних ферментів за результатами біохімічних досліджень сироватки крові новонароджених поросят до початку вживання молозива в порівнянні з клінічно здоровими поросятами першої доби життя, які вживали молозиво.

Завдання роботи: порівняння біохімічних показників крові поросят до початку вживання молозива та поросят першої доби життя.

Матеріали і методи дослідження. Було обстежено 10 поросят однієї породи, 5 клінічно здорових новонароджених - до вживання молозива (I група) і 5 - клінічно здорових першої доби життя (II група), які утримувались в умовах одного й того ж господарства. У сироватці крові тварин обох дослідних груп одноразово визначали вміст біохімічних показників (загального білка, альбумінів, глобулінів, сечовини, сечової кислоти, креатиніну, загального білірубіну і його фракцій, тимолову пробу та концентрацію глюкози). Результати визначали за загальноприйнятими методиками [2]. Дослідження проводили на базі клініко-діагностичної лабораторії «Медичні дослідження», Свідоцтво про Атестацію лабораторії №040-09 від 23.03.2009 року. Результати досліджень підлягали статистичній обробці. Достовірність відмінностей середніх величин визначали за допомогою критерію Стьюдента-Фішера.

Дослідження виконувалося відповідно до принципів Гельсінської декларації, прийнятої Генеральною асамблеєю Всесвітньої медичної асоціації (2000), Законом України «Про захист тварин від жорстокого поводження» від 21.02.2006 року №3447.

Результати досліджень. За результатом проведених нами попередніх досліджень, а також за даними інших авторів, можна стверджувати, що у тварин перших годин життя до прийому молозива спостерігається фізіологічна гіпопротеінемія $[7,9,11]$. Корабльова Т. Р. (1997) у своїх роботах вказує на той факт, що в перші 12-24 години 
після народження слизова оболонка тонкої кишки має високу проникливість, що обумовлює проникнення імуноглобулінів молозива в кровоносне русло, забезпечуючи тим самим як колостральний імунітет, із загально прийнятої точки зору, так i стимулюючи становлення власної системи органів імунного захисту, і є пусковим механізмом [3].

Про високу проникність стінки кишечнику для білків молозива свідчить підвищення концентрації загального білку у сироватці крові поросят першої доби життя після прийому молозива. Так, встановлено, що після надходження в організм новонароджених поросят молозива, рівень загального білку в сироватці крові збільшується на 37 \%. Кількість альбумінів у тварин цієї групи становила 50 \% від кількості загального білка й була на 30 \% меншою за таку в поросят першої групи. Ймовірно, така гіперальбумінемія має відносний характер і зумовлена тим, що поросята не одержували не лише поживних речовин у «домолозивному» періоді, але й необхідної кількості рідини.

3 надходженням молозива в організм у поросят зростає вміст глобулінів на 30 \%, що відповідно відбивається на рівні $\mathrm{A} / \Gamma$ коефіцієнта, а саме зменшення показника з 4,2 до 1,014.

Нами зафіксовано зниження вмісту сечовини до верхньої межі норми молодняку даного виду тварин (із 8,7 до 5,9 ммоль/л) та креатиніну ( 123,57 до 82). Зменшення кількості небілкових азотистих компонентів крові вказує на активізацію секреторної функції нирок і роботи печінки у поросят, починаючи 3 перших годин життя.

Концентрація загального білірубіну у тварин другої групи більше ніж удвічі переважно за рахунок збільшення непрямого білірубіну. Це явище отримало назву фізіологічна (транзиторна) жовтяниця. Цей стан належить до так званих пограничних станів новонароджених. За своїм характером цей вид жовтяниці відноситься до кон'югаційного. В основі цього процесу лежить перебудова системи гемоглобіну, що має місце після народження. Справа в тому, що гемоглобін плода відрізняється від гемоглобіну дорослого організму: під час внутрішньоутробного розвитку в організмі переважає гемоглобін F (HbF) (він краще зв'язує кисень), у порівнянні зі «звичайним», дорослим гемоглобіном А $(\mathrm{HbA})$, за рахунок чого й відбувається перехід кисню від материнських еритроцитів до еритроцитів плода. Невдовзі після народження організм починає інтенсивно руйнувати $\mathrm{HbF}$ iз тим, аби синтезувати НbА. Природно, процес розпаду гемоглобіну приводить до утворення непрямого білірубіну. Поскільки зв'язувальна здатність печінки в цьому віці невелика, концентрація білірубіну в крові починає поступово наростати [15].

У нормі вміст глюкози в сироватці крові свиней коливається в межах 4,72-8,33 ммоль/л. Новонароджене порося має досить обмежений запас глікогену, головним чином, у печінці [8]. Після надходження в організм поросят молозива кількість глікогену збільшилася майже втричі, а саме з 2,67 до 5,88 ммоль/л.

У «домолозивному» періоді активність АлАТ і AcАТ у сироватці крові поросят нижча, ніж у тварин, які вживали молозиво, а саме у 4,5 та 5,6 рази. Відповідно, коефіцієнт Де-Рітіса був вищим у поросят другої групи у 1,2 разу.

Активність ГГТП, лужної фосфатази та $\alpha$-амілази суттєво не відрізнялась.

Активність загальної ЛДГ- представника класу оксидоредуктаз - у тварин у «домолозивному» періоді нижча у 1,4 разу, ніж у поросят після вживання молозива, що свідчить про низький рівень гліколізу й узгоджується 3 наявністю гіпоглікемії. Навіть у короткий період життя після народження спостерігається зростання (у 1,7 разу) активності загальної КФК, що може свідчити про активізацію роботи м'язової тканини.

На нашу думку, зростання вмісту тригліцеридів у 2,5 разу та холестеролу у 1,7 є показником більш активного синтезу нейтральних ліпідів у тварин, які отримали молозиво.

Спостерігається зниження вмісту глікопротеіну серомукоїда з 0,16 до 0,124 ум. од.

Концентрація загального сироваткового кальцію в поросят обох груп не відрізнялась і співпадала 3 даними, отриманими нами раніше щодо поросят 4-місячного віку (2,56 $\pm 0,03$ ммоль/л). Тобто, рівень загального кальцію в сироватці крові вже був сталою величиною, починаючи від самого народження

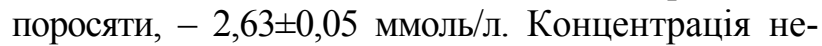
органічного фосфору, навпаки, виявилася більшою на 32 \% у тварин старшої вікової групи.

Таким чином, рівень майже всіх показників клінічного метаболізму (собливо білкових фракцій) у сироватці крові поросят у «домолозивному» періоді значно відрізняється від показників поросят першої доби життя, які отримували молозиво. Зміна показників білкового обміну пов'язана 3 надходженням в організм білків молозива. Можна припустити, що підвищення активності АлАТ, ЛДГ рівня вмісту глюкози, концентрації загального білірубіну при зниженні лужної фосфатази та сечовини в крові у поросят першої доби життя пов'язано зі стресовим фактором, отриманим організмом під час та відразу після пологів. 
ВЕТЕРИНАРНА МЕДИЦИНА

\begin{tabular}{|c|c|c|}
\hline \multicolumn{3}{|c|}{ Біохімічні показники поросят першої доби жсиття } \\
\hline Показник & I група & II група \\
\hline Загальний білок, г/л & $34,57 \pm 0,92$ & $55 \pm 0,89$ \\
\hline Альбуміни, г/л & & $27,4 \pm 0,24$ \\
\hline Глобуліни, г/л & & $27,4 \pm 0,98$ \\
\hline Альбумін, \% & $80,7 \pm 0,28$ & $50,24 \pm 1,02$ \\
\hline Глобулін, \% & $19,3 \pm 0,28$ & $49,76 \pm 1,02$ \\
\hline A/Г коефіцієнт & $4,2 \pm 0,07$ & $1,014 \pm 0,04$ \\
\hline Сечовина, ммоль/л & $8,7 \pm 0,22$ & $5,9 \pm 0,21$ \\
\hline Креатинін, мкмоль/л & $123,57 \pm 4,53$ & $82 \pm 3,36$ \\
\hline Білірубін загальний, мкмоль/л & $8,01 \pm 0,06$ & $18 \pm 0,89$ \\
\hline Білірубін прямий, мкмоль/л & $3,07 \pm 0,05$ & $4,4 \pm 0,4$ \\
\hline Білірубін непрямий, мкмоль/л & $4,94 \pm 0,1$ & $13,6 \pm 0,6$ \\
\hline Тимолова проба, Од $\mathrm{SH}$ & $2,27 \pm 0,12$ & $2,16 \pm 0,07$ \\
\hline Глюкоза, ммоль/л & $2,67 \pm 0,12$ & $6,88 \pm 0,3$ \\
\hline АлАТ, од/л & $13,99 \pm 1,73$ & $63,8 \pm 1,74$ \\
\hline АсАТ, од/л & $23,56 \pm 3,31$ & $132 \pm 4,85$ \\
\hline Коеф. Де-Рітіса & $1,71 \pm 0,17$ & $2,09 \pm 0,13$ \\
\hline ГГТП, од/л & $82,43 \pm 6,44$ & $98 \pm 5,45$ \\
\hline Лужна фосфатаза, од/л & $2448,6 \pm 93,87$ & $2266,2 \pm 148,5$ \\
\hline$\alpha$-амілаза, од/л & $3425,1 \pm 246,83$ & $3446,2 \pm 41,8$ \\
\hline КФК, од/л & $264,7 \pm 45,07$ & $478,2 \pm 35,95$ \\
\hline ЛДГ, од/л & $932,1 \pm 118,66$ & $1414,2 \pm 103,35$ \\
\hline Холестерин, ммоль/л & $1,11 \pm 0,10$ & $1,876 \pm 0,098$ \\
\hline Тригліцериди, ммоль/л & $0,50 \pm 0,03$ & $1,266 \pm 0,17$ \\
\hline Серомукоїд, ум. од. & $0,16 \pm 0,02$ & $0,124 \pm 0,005$ \\
\hline Кальцій, ммоль/л & $2,63 \pm 0,05$ & $2,636 \pm 0,026$ \\
\hline Неорг. фосфор, ммоль/л & $1,2 \pm 0,07$ & $1,758 \pm 0,05$ \\
\hline
\end{tabular}

\section{Висновки:}

1. Рівень більшості показників клінічного метаболізму, передусім, білкових фракцій, у сироватці крові поросят у «домолозивному» періоді значно відрізняється від показників поросят першої доби життя, які отримували молозиво.

2. Зміна показників білкового обміну у поросят першої доби життя пов'язана 3 надходженням в організм імунних білків молозива, що при-

\section{БІБЛІОГРАФІЯ}

1. Головко В. О. Вплив мікроклімату на кратність прийому молозива поросятами-сисунами та їх резистентність / В. О. Головко, М. В. Чорний, С. О. Хомутовська / Біла Церква, 2010. - Науковий вісник ветеринарної медицини. - Збірник наукових праць. - Випуск 5 (78).

2. Камышшников В. С. Справочник по клиникобиохимической лабораторной диагностике. - Т.1 / [В. С. Камышников] - Минск: Беларусь, 2000. $495 \mathrm{c}$.

3. Кораблева T. Р. Иммунные структуры органов пищеварения // Т. Р. Кораблева, Н. П. Барсуков / зводить до збільшення концентрації загального білка (на $37 \%$ ), вмісту глобулінів (на $30 \%$ ), зменшення альбумінів (на $30 \%$ ).

3. Підвищення активності АлАТ, ЛДГ вмісту глюкози, концентрації загального білірубіну за зниження активності лужної фосфатази та концентрації сечовини в крові, ймовірно, пов'язані 3 дією стресового фактора на організм під час та відразу після пологів.

Симферополь, 1997. - 78 с.

4. Лісова В. В. Патоморфологія вікового імунного дефіциту в поросят новонародженого періоду в умовах промислового комплексу / В. В. Лісова, Ю. Годованюк / Науковий вісник національного університету біоресурсів і природокористування України, 2012. - №172, Ч. 2. - С. 88-91.

5. Лях Ю. Г. Влияние стрессов на реакцию белков и гематологические показатели крови поросят / Ю. Г. Лях, Л. А Крот / Вісник Сумського національного аграрного університету, 2005. №1-2 (13-14). - C. 98-100. 
6. Мейер Д. Ветеринарная лабораторная медицина. Интерпретация и диагностика / Д. Мейер, Дж. Харви; [пер. с англ. Л. А. Певницкого; под ред. Ю. М. Кеда]. - М. : Софион, 2007. - 456 с. : ил. 7. Панікар I. I. Метаболічний профіль сироватки поросят до вживання молозива / I. I. Панікар / Науковий вісник Луганського НАУ, Ветеринарні науки. - 2012, №40. - С. 138-141.

8. Панікар I. I. Ферментативна активність сироватки крові поросят у до молозивний період / I. I. Панікар / Проблеми зооінженерії та ветеринарної медицини. Ветеринарні науки. - 2012. Вип. 25. - Ч. 2. - С. 51-54.

9. Понд У. Дж., Хаупm К. А. Биология свиньи. М. : Колос, 1983. - $331 \mathrm{c.}$

10. Ткачук О. Д. Вплив мікроклімату на основні показники резистентності свиней // Вісник Полтавської державної аграрної академії, 2010. № 2. - C. 136-138.

11. Хандкарян В. Н. Получение, выращивание и использование поросят-гнотобиотов при изучении респираторных и желудочно-кишечных болезней свиней: автореф. дис. ... кандидата вет. наук ; спец. 16.00.03 - «Ветеринарная микробиология, вирусология, эпизоотология и микология» / В. Н. Хандкарян. - Полтава, 1987. - С. 20.

12. Чумаченко В. Ю. Хвороби імунної системи у тварин. Імунітет. Механізми та фактори, що зумовлюють його стан / В. Ю. Чумаченко, В. В. Чумаченко / Ветеринарна медицина України. - 2008. № 10. - С. 19.

13. Хвороби свиней / В. І. Шевченко, В. П. Заярнюк, І. В. Папченко [та ін.] / Біла Церква : Білоцерківський ДАУ, 2005. - 168 с.

14. Bulter J. Development of the neonatal B and T cell repertoire in swine: implications for comparative and veterinary immunology // J. Bulter, M. Sinkora, N. Wertz // Vet. Res, 2006 - Vol. 37. P. 417-441.

15. Sinkora J. Early development of immune system in pigs // J. Sinkora, Z. Rehakova, M. Sinkora // Vet. Immunol. Immunopathol. 2002. - Vol. 87. - P. 301306.

16. http://semya.com.ua/newborn/31-govtjanici. html 